\title{
Material or Material Leachate Pyrogenic Problem
}

National Cancer Institute

\section{Source}

National Cancer Institute. Material or Material Leachate Pyrogenic Problem. NCI

Thesaurus. Code C92077.

The undesirable presence of pyrogens or fever-producing organisms caused by materials that permeate through the device. 